\title{
Political Environment and Implementation of Public Private Partnership Infrastructure Development in Kenya
}

\author{
Moses K. Baithili, \\ Kirema Nkanata Mburugu, PhD \\ Duncan Mugambi Njeru, PhD \\ University of Embu, Kenya
}

Doi:10.19044/esj.2019.v15n19p282ＵRL:http://dx.doi.org/10.19044/esj.2019.v15n19p282

\begin{abstract}
Public Private Partnership (PPP) is a long term agreement between the public and private sector where risks and rewards are shared in developing a public facility. Private sector play a monumental role in bridging public finance deficit on capital projects. In Kenya, the government has created an enabling environment for private sector participation in the country's infrastructure development which is meant to spur economic growth. This study sought to establish the effect of political environment on the implementation of Public Private Partnership infrastructure development projects in Kenya. The cross-sectional descriptive survey research methodology was used in the study. The population of the study was sixtythree PPP projects being implemented in Kenya across different sectors. One project was used in pretesting of research instruments. Therefore, the actual population used in the study was sixty-two projects. The study adopted systematic sampling technique where the first $n^{\text {th }}$ element was randomly selected. A sample size of 31 was selected from the sampling frame using sampling fraction. Questionnaires were administered to procurement officers charged with implementation of PPPs in the sampled organizations. To ensure validity of the data, the research questionnairre was verified by experts made up of the research supervisors. The research instruments were pretested during pilot study. Qualitative data was analyzed and presented through descriptions while the quantitative data was analyzed using descriptive statistics, measures of central tendency, measures of dispersion and inferential statistics. Multiple regression analysis was used to determine the relationship between dependent and independent variables. The study found that most of the organizations were in the initial stages of implementation of PPPs. The majority of the respondents considered the political environment in Kenya unstable because of the disputed presidential elections which was happening at the time the data
\end{abstract}


was collected. The study also found political environment had significant influence on the implementation of PPPs in Kenya. The respondents also identified corruption, poor project selection, lack of experts and cost over-runs as other factors that affected implementation of PPPs. The results of the study will inform policy makers in public entities, County and National Governments to put in place necessary mechanisms to manage politics and fight corruption to increase uptake of Public Private Partnership for infrastructure development in Kenya.

Keywords: Micro Environment, macro environment, implementation of public private partnerships

\section{Background of the Study}

Private-Public Partnerships (PPP) are defined as long term agreements whereby public and private entities share resources for the purpose of developing a public facility (Mouraviev \& Kakabadse, 2016). In a PPP arrangement, risks and rewards are shared by the two entities through a predetermined criterion expressly documented to safeguard the interests of each party because of the antagonistic interests of the parties involved. Bhasin and Sadhu (2010) observe that PPP is an institutionalized relationship where a public and private entity engage each other for the purpose of making profits and contribute to social responsibility. The parties jointly participate in defining objectives, methods and framework of collaboration in implementation of the proposed development project.

The idea behind PPPs is to enable the private sector to invest in the public sector by bringing on board new sources of financing to fund capital intensive public infrastructure development projects that enhance service delivery to the public by bridging the financing gap that exists in the public purse (Rangi, 2013). These sentiments are further shared by Mzikayise (2009) who argues that through PPPs, governments are able to provide services to citizens. Khaled, Nor'Aini and Ernawati (2015) also noted that PPPs are a successful means of providing public utilities because each entity involved has a comparative advantage in performance of specific duties outlined in the collaboration framework.

World governments and government agencies are increasingly adopting Public Private Partnerships as a means for providing services to their citizens. Emilija (2013) conducted a study in Serbia on the cooperation between University of Belgrade and Coca-Cola Company. He observed that through PPPs, corporates contributed to community development through cooperation to improve access to education. To accelerate uptake of PPPs Kaur (2012) proposes that governments should be in a position to provide subsidies to private entities engaged in PPPs. As a result, there is potential for 
increased developments that support public utility. In the case of South Africa Fombad (2015) found that the success of PPP projects hinges on the effectiveness of governance structures put together by the collaborating organizations. The governance structures include the aspect of managing organizational politics that impact on the overall implementation of the project. Therefore, governance structures must be forward looking in terms of identifying and mitigating risks that have the potential to negatively impact a PPP project. According to Ngowi (2011) increasing population and scarcity of resources have led to deterioration of service delivery in African countries. This strain on the available infrastructure, has necessitated collaboration of public and private sector through PPP arrangements in an attempt to improve service delivery. Gor and Gitau (2010) say that the idea of PPPs is the only sustainable model of financing available for such capital intensive infrastructure in developing countries.

Studies carried out in Kenya reveal that the PPP financing model is an important ingredient for realizing development because of the scarcity of resources at the public coffers. For example, Kimani, Waweru and Omondi (2015) propose that public universities in Kenya adopt PPPs to increase accommodation of students because of the decreasing state financing. On the other hand, Bakibinga, Ettarh, Ziraba, Kyobutungi, Kamande, Ngomi and Osindo, (2014) pointed out that PPPs should not be limited to certain sectors but should also include other sectors especially those that serve the low income earners in society. This arrangement is the most practical way for a country to realize development that propels economic growth without increasing public debts.

In Kenya, PPPs officially started with the enactment of the Public Procurement and Disposal Act of 2005 and sessional paper No.2 of 2005 on Privatization of State Corporations and Investments. These documents provided legal basis through which public and private entities could engage to realize improved service delivery. The gains made were further enhanced with the enactment of Public Private Partnership Act of 2013. The Act allows the participation of the private sector in the financing, construction, development, operation or maintenance of infrastructure through concession or other contractual arrangements. The Act provides for various types of PPPs which include; Buy-Build-Operate (BBO), Build-Lease-Operate-Transfer (BLOT), Build-Own-Operate (BOO), Transfer-Build-Operate-Transfer (TBOT), Design-Build (DB), Design-Build-Finance-Operate (DBFO) and Operation \& Maintenance Contract (O\&MC). In addition, it allows for the establishment of institutions to regulate, monitor and supervise the implementation of project agreements on infrastructure, development projects and connected purposes.

As a result, the Government of Kenya (GoK) has prioritized PPP as a feasible way to achieve infrastructural development that is are critical in 
realizing Vision 2030. This is because the Constitution of Kenya 2010 created more demand for resources to fund County Governments and specifically development projects creating a bigger financing gap hence the need for PPPs. As a result of the need for increased resource expenditure in infrastructural development, increasing population and its ability to stimulate economic growth, adoption of PPPs financing model is inevitable for Governments (Straub, 2008; Rania, 2008).

\section{Political Environment}

Politics plays a vital role in the success of PPPs around the world. Daniel, Germà and Albert (2019) acknowledge that the politics surrounding PPPs can negatively impact on PPP projects because of cost over runs and sometimes politics may turn them into white elephant projects. This observation creates the need to manage politics by ensuring operational risks are mitigated early enough through sound governance structures. The most effective way of managing politics is by building consensus through public education, consultative engagement and ensuring transparency and oversight in the management of PPP projects. For example, Mzikayise (2009) developed a Participatory Development Systems Model (PDSM) which emphasizes on involvement of local communities in PPP projects as a means of effective governance. The involvement of local communities is not only important in managing politics, but increases project ownership among people and innovation in the overall project. The involvement of project beneficiaries is instrumental in managing multiple interests that usually arise in PPP projects. Therefore, it is difficult to divorce politics from PPP projects hence the need for constant consultation with stakeholders. Therefore, this study sought to establish the role of political environment on implementation of PPPs in Kenya.

\section{Statement of the Problem}

The promulgation of the Kenyan Constitution in 2010 brought about County Governments. These counties and the need to repair, maintain and develop new infrastructure added strain to the government's available resources to support development as envisioned in the Kenya Vision 2030 blue print. In view of capital projects financing challenges, the government continues to encourage partnership between the public and private sector and other stakeholders like the donor community (Suchman, Hart \& Montagu, 2018). This is demonstrated by the Government's commitment on legal reforms that is demonstrated by the enactment of Public Private Partnership Act of 2013. The Act is intended to accelerate uptake of PPP projects by providing necessary legal safeguards against risks that have potential to hinder adoption of PPPs in Kenya. 
The World Bank (2017) in its annual report noted that only twenty-six projects have been completed in Kenya under PPP in the period between 1990 to 2016. Of the twenty-six projects, eighteen are in the energy sector, four transport, three in ICT and one in water and sanitation. The report further indicated that two major projects that accounted for $75 \%$ of the total investments under PPP in Kenya during the period were cancelled due to political interference. In addition, data from the National Treasury indicates that there are only sixty-three PPP projects being implemented in Kenya. These projects are in different stages of implementation. Many of these projects however remain in the early stages of implementation even in instances where such projects have taken long since they were initiated.

This provides a paradox because despite robust legal reforms, improved political environment and greater involvement of people in decision making; the uptake, implementation and investment of PPPs in Kenya has not been impressive. Therefore, the study sought to establish the influence of political environment in implementation of PPP infrastructure development in Kenya.

\section{Objective of Study}

The objective of the study was to determine the influence of political environment on implementation of Public Private Partnership infrastructure Developmentin Kenya. The study covered the $\mathrm{xx}$ organizations that are implementing PPP projects in Kenya as at 28th June, 2018().

\section{Empirical Review}

The Government and the Private Sector often underestimate the extent and effect of politics on the implementation of the PPP projects. For example, political opposition is greatly reduced when authorities engage stakeholders on a public discussion and allow debate around the issue of PPPs. It is imperative to note that various stakeholders in a PPP arrangement have vested interests and opinions hence the need to accommodate their divergent opinions. In order for governments to succeed, there is need to manage politics by building consensus through public education and consultative mechanisms and by ensuring transparency in award and oversight of PPPs (Twitchen \& Adams, 2012). This view was further advanced by Mzikayise (2009) in his Participatory Development Systems Model (PDSM) when he argued that participation of local communities provides an opportunity for effective governance of PPP projects. These studies lay emphasis on the involvement of the public in decisions relating to implementation of PPPs. The previous studies were conducted in a different context and methodologies used differed with the current study. 
Sachs, Tiong and Wang (2007) observed that PPPs usually involve huge investments that make them attractive to political interests. As such, PPP projects are often politicized both at the international, national or regional level because of the huge investments. This argument was supported by Opara, Elloumi, Okafar and Warsame (2017) who suggested that political leadership was an important element in the implementation of PPPs. The study was conducted in Canada, therefore, the context of political environment could be different from the Kenyan situation. The researchers observed that Alberta for a long time had one-party government that ensured political stability unlike in the Kenyan situation that is characterized by pluralistic politics. The study found out that political leaders who supported PPPs in Alberta were more popular among the electorate and generally stood higher chances of being elected. The study adopted longitudinal case study unlike the current study that adopted cross-sectional survey methodology. In a nutshell, politicization of PPPs can be a real threat to implementation of PPPs in Kenya as politicians seek popularity.

In Kenya, Musyoka, (2012) conducted a study on factors influencing performance of PPPs in the housing sector. The study failed to focus on the influence of the wider political environment but limited itself to political violence. In addition, it focused on a narrow sector of housing without looking at the other developments where the public can partner with private sector. This study focused on political environment in a broader sense beyond political violence and support of political leadership that implemented PPP projects. In addition, the study did not focus on a specific sector but on general PPP development projects implemented through PPPs in Kenya.

Jacobson and Choi (2008) conducted a study that found citizen involvement was important for successful implementation of PPPs because private sector is mainly motivated by profits. Therefore, they have a potential to compromise on quality hence the need for vigilant monitoring by both project beneficiaries and political leadership. The study also emphasized on open communication and trust, that can only be achieved through frank and sincere engagement of the public. This study focused on stakeholder engagement as the central point through which target beneficiaries of PPP projects get involved in the implementation of such projects. In analyzing the political environment variable, the study focused on the following indicators; stakeholder involvement, court cases on PPP projects, political support and the popularity of the leaders implementing PPP projects.

\section{Theoretical Review}

There are a number of theories that can be used to explain issues that affect implementation of Public Private Partnership. The current study was guided by agency theory. 


\section{Agency Theory}

Agency theory was first advanced by Stephen Ross and Barry Mitnick and later enhanced by Michael Jensen and William Meckling. It explains the principal-agent relationship and states that divergence always exists in principal-agent relationship because of conflicting interests. The theory applies to circumstances in which one actor who is the principal delegates duties and responsibilities to another who is referred to as an agent. The principal ought to make sure that duties are undertaken the way he wants them to be (Jensen \& Meckling, 1976). This principal-agent relationship is also observed when the buyer (regarded as principal) engages a supplier (regarded as an agent) to deliver goods or services on his/her behalf. The theory acknowledges agency problem that occurs when cooperating parties have divergent interests (Walaa, 2018).

In Public Private Partnership, the public entity provides the private entity with the best enabling environment to conduct business to make profit. In so doing, the private entity is obliged to support the public entity advance its social agenda of infrastructure development. Given the private partner is in business, the public entity enters into agreement with the private entity on the mechanisms to operate the infrastructure so as to recoup the investment plus the profit accrued thereon. During the implementation of the project the public entity is bound to monitor the progress of the project either by itself or through an external body to ensure compliance with the agreement signed between the public and private entity in terms of quality of service delivery, project timelines, and contract specifications among others (Parker, Dressel, Chevers \& Zeppetella, 2018). Therefore, PPP is meant to advance principal-agent relationship in which one party (The Principal-Public) delegates its responsibility to another (The Agent-Private) who performs the work on behalf of the Principal.

\section{Conceptual Framework}

In this study, political environment was an independent variable while implementation of Public Private Partnerships in Kenya was a dependent variable as shown in figure 1. The objective of the study was to examine the relationship that exists between political environment as an independent variable and implementation of PPPs as an independent variable. 


\section{Political Environment \\ - Stakeholders \\ - Court cases on PPP projects \\ - Political Support of PPPs \\ - $\quad$ Leadership popularity}

Levels of Implementation of Public Private Partnership Projects

- $\quad$ Project preparation and appraisal

- Request for qualification

- Request for proposals

- $\quad$ Project Construction \& Management

Figure 1: Conceptual framework on the influence of political environment on implementation of PPP projects in Kenya

\section{Relationship between political environment and implementation of PPPs}

The ability of PPP to thrive in a given location is dependent on the project acceptability by beneficiaries, political stability and the political support that the project enjoys. Political environment can be managed by building consensus through public education and consultative mechanisms like holding stakeholders meetings and by ensuring transparency in the award and the oversight of PPPs (Twitchen \& Adams, 2012). Jacobson and Choi (2008) found out that political support was important for successful implementation of PPPs. The study further emphasized on open communication and trust, through frank and sincere engagement of the public as a prerequisite for a conducive political environment. These observations point to the important role that political environment plays in ensuring that PPP projects are successful. The study specifically focused on stakeholder involvement, court cases, political support and popularity of political leadership who implemented PPPs.

\section{RESEARCH METHODOLOGY}

\section{Research Design}

The study adopted a cross-sectional descriptive research design to determine the influence of political environment on the implementation of Public Private Partnership projects in Kenya. Cross-sectional survey is useful because it offers an opportunity to evaluate individual's perspective and experience concerning a certain phenomenon (Alderman \& Salem, 2010).

\section{Target Population}

The taget population was all projects being implemented under PPP financing arrangement in Kenya. The selected projects were from across all sectors and organizations as captured in the PPP project list by the National 
Treasury as at $28^{\text {th }}$ June, 2018 available on https://pppunit.go.ke/. The information was collected from officers charged with implementation of sampled PPP projects. According to the list of PPP projects, a total of sixtythree PPP projects were being implemented at the time in Kenya. Therefore, a population of sixty three PPP projects was targeted in the study where one project was selected in a pilot study. This implies that sixty-two projects were used in the actual study.

\section{Sampling techniques Sample Size \& Sampling Frame}

The study adopted systematic sampling of sixty two projects under the PPP financing model in Kenya. According to Saunders, Lewsis and Thornhill (2009) a systematic sampling is appropriate for collecting data in both large and small cases where there is time and financial constraints. Therefore, the choice of the technique was influenced by the distribution of PPP projects across the country which could create financial strain if census was to be adopted. The projects were systematically arranged from where the sample size was determined using sampling fraction. The first project was randomly selected to ensure the projects were not selected in predetermined intervals.

The sampling fraction was:

Sampling fraction $=62 / 31=2$ which is approximately $1 / 2$

Therefore in every $2^{\mathrm{n}}$ element of the project was selected.

\begin{tabular}{lllllllllll}
\multicolumn{10}{c}{ Table 3. 1: Sampling fraction } \\
11 & 1 & 2 & 3 & 4 & 5 & 6 & 7 & 8 & 9 & 10 \\
22 & 23 & 13 & 14 & 15 & 16 & 17 & 18 & 19 & 20 & 21 \\
33 & 34 & 35 & 25 & 26 & 27 & 28 & 29 & 30 & 31 & 32 \\
44 & 45 & 46 & 47 & 48 & 38 & 39 & 40 & 41 & 42 & 43 \\
55 & 56 & 57 & 58 & 59 & 60 & 61 & 62 & 52 & 53 & 54 \\
\multicolumn{7}{c}{ Based on the above projects, the sample size of the study was 31. }
\end{tabular}

\section{Data Collection Instruments}

The study used both primary and secondary sources of data. On the primary sources, self administered questionnaires were issued to respondents. The questionnaire used both closed and open ended questions to enhance accuracy. The secondary sources of data involved information obtained from journals, reports, the PPP unit website and libraries.

\section{Data Collection Procedures}

The respondents were approached through the heads of identified organizations to enhance response rate from the respondents. Research questionnaires were dropped to the respondent and picked at agreed dates by the research assistant. 


\section{RESEARCH RESULTS \\ Response Rate}

The study involved administration of questionnaires to the individuals in-charge of PPP projects in the selected organizations. A total of 31 questionnaires were administered as per the number of projects selected. The questionnaires were filled in and returned to the researcher. The response rate was $100 \%$ of the total questionnaires administered. The high response rate can be attributed to the collection procedure adopted where the researcher personally administered questionnaires and assured respondents of the confidentiality of the information given.

\section{Implementation of Public Private Partnership}

This section comprises of the analysis of the dependent variable of the study to determine the extent of implementation of PPP projects in Kenya. The study sought to determine the extent to which respondents agreed with various statements in regard to implementation of PPP projects according to levels of implementation. These levels of implementation were; Project preparation and appraisal, Request for qualification, Request for proposal and Project construction and management

\section{Project Preparation and Appraisal}

The indicators of project preparation and appraisal were; project identification, selection and prioritization, appointment of institutional node, appointment of transactional advisory and feasibility study. The results are presented in Table 4.5

Table 4.5: Project Preparation and Appraisal

\begin{tabular}{|c|c|c|c|c|c|c|c|}
\hline Variables & 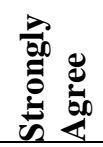 & 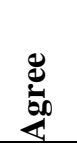 & 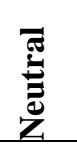 & 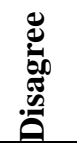 & 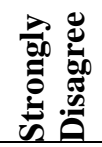 & 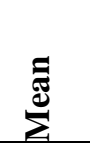 & 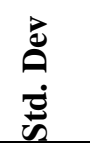 \\
\hline Project identification & $52 \%$ & $48 \%$ & $0 \%$ & $0 \%$ & $0 \%$ & 4.52 & .508 \\
\hline $\begin{array}{l}\text { Selection and Prioritization of } \\
\text { project }\end{array}$ & $50 \%$ & $50 \%$ & $0 \%$ & $0 \%$ & $0 \%$ & 4.50 & .509 \\
\hline $\begin{array}{l}\text { Appointment of Institutional } \\
\text { Node }\end{array}$ & $45 \%$ & $45 \%$ & $10 \%$ & $0 \%$ & $0 \%$ & 4.35 & .661 \\
\hline $\begin{array}{l}\text { Appointment of Transanctional } \\
\text { Advisory }\end{array}$ & $45 \%$ & $45 \%$ & $7 \%$ & $3 \%$ & $0 \%$ & 4.32 & .748 \\
\hline Feasibility study conducted & $43 \%$ & $30 \%$ & $10 \%$ & $10 \%$ & $7 \%$ & 3.93 & 1.258 \\
\hline
\end{tabular}

The result on Table 4.5 indicate that $52 \%$ (mean=4.52, $S t d=0.508$ ) of the respondents strongly agreed that project identification had been concluded. 
$50 \%$ of the respondents strongly agreed and other 50\% agreed with the statement that selection and prioritization of projects had been done in their organizations. In addition, results revealed that $45 \%$ of the respondents strongly agreed and $45 \%$ agreed to the appointment of institutional node and appointment of transactional advisory had been finalized in their organization. Finally, $43 \%$ and $30 \%$ of the respondents strongly agreed and agreed respectively that feasibility study had been conducted in their organization. The results show that majority of the organizations implementing PPP projects have achieved this level of implementation. The high achievement rate is an indication of increased interest on PPP projects because of the financial constrain that often faces public projects that are state funded. The state resources in most cases are constrained because of competing interests from other sectors of the economy.

\section{Request for Qualification}

The indicators for this variable are; preparation of RFQ documents, advertisement of RFQ and prequalification of companies. The results are presented in Table 4.6

Table 4.6: Request for Qualification

\begin{tabular}{|c|c|c|c|c|c|c|c|}
\hline Variables & 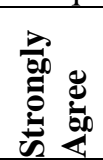 & 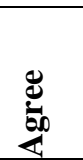 & $\begin{array}{l}\bar{T} \\
\bar{E} \\
\bar{E}\end{array}$ & 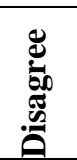 & 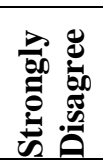 & $\stackrel{\Xi}{\Xi}$ & $\begin{array}{l}\vec{\Xi} \\
\dot{0} \\
\dot{0}\end{array}$ \\
\hline Preparation of RFQ documents & $26 \%$ & $37 \%$ & $\begin{array}{l}17 \\
\%\end{array}$ & $7 \%$ & $13 \%$ & $\begin{array}{l}3.5 \\
7\end{array}$ & 1.331 \\
\hline Advertisement of RFQ & $27 \%$ & $33 \%$ & $\begin{array}{l}20 \\
\%\end{array}$ & $7 \%$ & $13 \%$ & $\begin{array}{l}3.5 \\
3\end{array}$ & 1.332 \\
\hline $\begin{array}{l}\text { Prequalification or Shortlisting of } \\
\text { companies }\end{array}$ & $30 \%$ & $30 \%$ & $\begin{array}{l}20 \\
\%\end{array}$ & $7 \%$ & $13 \%$ & $\begin{array}{l}3.5 \\
7\end{array}$ & 1.357 \\
\hline
\end{tabular}

According to the results presented on Table 4.6, 37\% of the respondents agreed with the statement that preparation of RFQ documents had been finalized, $26 \%$ strongly agreed while $13 \%$ strongly disagreed with the statement (mean=3.57, Std=1.331). On advertisement of RFQ, 33\% of the respondents agreed with the statement, 27\% strongly agreed, 20\% were neutral, 7\% disagreed and 13\% strongly disagreed (Mean=3.53, Std=1.332). On prequalification of companies, $30 \%$ of the respondents strongly disagreed, $30 \%$ disagreed, $20 \%$ were neutral, $7 \%$ disagreed and 13\% strongly disagreed (mean=3.57, Std=1.357). Based on the responses, majority of the respondents in the study indicated that the request for qualification level had been achieved in the sampled organizations. This implies that there is high interest for public private partnerships projects by public entities in Kenya. 


\section{Request for Proposal}

The indicators for this variable are; invitation of prequalified bidders to submit RFP, evaluation of bids, negotiation and award and signing of contracts. The results are presented in Table 4.7

Table 4.7: Request for Proposal

\begin{tabular}{|c|c|c|c|c|c|c|c|}
\hline Variables & 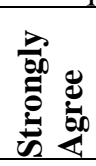 & 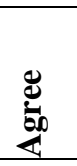 & 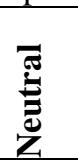 & 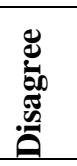 & 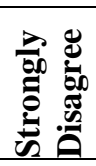 & 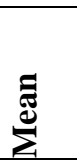 & 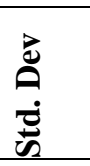 \\
\hline $\begin{array}{l}\text { Invitation of Prequalified bidders to } \\
\text { submit RFP }\end{array}$ & $30 \%$ & $23 \%$ & $20 \%$ & $7 \%$ & $20 \%$ & 3.37 & 1.497 \\
\hline Evaluation of bids conducted & $26 \%$ & $32 \%$ & $16 \%$ & $7 \%$ & $19 \%$ & 3.39 & 1.453 \\
\hline Negotiation conducted & $23 \%$ & $30 \%$ & $20 \%$ & $7 \%$ & $20 \%$ & 3.30 & 1.442 \\
\hline Award and signing of contract & $23 \%$ & $16 \%$ & $13 \%$ & $26 \%$ & $23 \%$ & 2.90 & 1.513 \\
\hline
\end{tabular}

The findings on Table 4.7 indicate that $30 \%$ of the respondents strongly agreed, 23\% agreed and 20\% disagreed with the statement that invitation of prequalified bidders to submit RFP had been concluded (Mean=3.37, Std =1.497). On evaluation of bids, $26 \%$ of the respondents strongly agreed, $32 \%$ agreed and $19 \%$ disagreed with the statement (Mean=3.39, Std=1.453). Among the respondents, 23\% agreed negotiations had been conducted, $30 \%$ agreed while $20 \%$ disagreed with the statement (Mean=3.30, Std=1.442). On the award and signing of the contract, $23 \%$ of the respondents agreed with the statement, $16 \%$ agreed while $26 \%$ disagreed and $23 \%$ strongly disagreed with the statement. The results show a steady decline in the number of contracts that have been signed and awarded compared to the previous levels. The respondents attributed the decline to the political interests that PPP projects tend attract because of the intensive capital involved. Political interference is most often the cause of the corruption cases reported in PPP projects. This observation resonates with Carpintero and Siemiatycki (2016) argument that political interference breeds corruption in projects that are capital intensive.

\section{Project Construction \& Management}

The indicators for this variable are; construction commencement, construction completion, operation of the project and project handing-over. The results are presented in Table 4.8. 
Table 4.8: Project Construction \& Management

\begin{tabular}{|c|c|c|c|c|c|c|c|}
\hline & 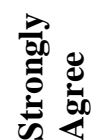 & 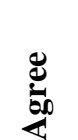 & $\begin{array}{l}\overline{\overparen{J}} \\
\bar{Z}\end{array}$ & 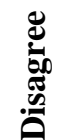 & 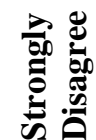 & 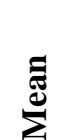 & $\begin{array}{l}\vec{D} \\
\dot{0} \\
\dot{D}\end{array}$ \\
\hline Construction Commenced & $10 \%$ & $13 \%$ & $14 \%$ & $23 \%$ & $40 \%$ & 2.30 & 1.393 \\
\hline Construction Completed & $10 \%$ & $13 \%$ & $15 \%$ & $26 \%$ & $36 \%$ & 2.36 & 1.355 \\
\hline Operation of the Project & $10 \%$ & $13 \%$ & $16 \%$ & $25 \%$ & $36 \%$ & 2.35 & 1.355 \\
\hline $\begin{array}{l}\text { Handingover of the project } \\
\text { completed }\end{array}$ & $10 \%$ & $7 \%$ & $21 \%$ & $23 \%$ & $39 \%$ & 2.26 & 1.316 \\
\hline
\end{tabular}

The findings on table 4.8 revealed that $40 \%$ of the respondents strongly disagreed with the statement, $23 \%$ disagreed, $14 \%$ were neutral, $13 \%$ agreed and $10 \%$ strongly agreed $($ Mean $=2.30, \quad S t d=1.393)$. On construction completion, $36 \%$ of the respondents strongly disagreed with statement. The other 26\% agreed and 15\% were neutral (Mean=2.30, Std=1.393). On operation of the project, $36 \%$ of the respondents strongly disagreed with the statement that the PPP project was operational. 25\% disagreed while $16 \%$ were neutral (mean=2.35, Std $=1.355)$. Finally, 39\% of the respondents strongly disagreed with the statement that handing over had been conducted while $23 \%$ disagreed (mean $=2.26$, Std $=1.316$ ). The findings on this level of implementation reveal most of the PPP projects did not reach project construction and management stage. This scenario contradicts the initial interest demonstrated by organizations adopting PPP model during project preparation and appraisal stage. The success of implementation of PPP projects during the initial stages can be attributed to organization's interest in seeking funding for projects that require high capital against limited resources available. However, the success of implementation declines as implementation moves to higher levels. The decline can be attributed to political interference, legal challenges, bureaucracy, risks, environmental changes, economic dynamics among other challenges that might not have been adequately planned during the initial stages of implementation.

\section{Political Environment.}

The objective of the study was to determine the influence of political environment on implementation of PPP projects in Kenya. The respondents were asked to indicate the extent to which they agreed with various statements on the influence of political environment on implementation of PPPs in Kenya. The results are presented in Table 4.11, Table 4.12 and Table 4.13. 
Table 4.11: Political Environment

\begin{tabular}{lll}
\hline & Frequency $(\mathbf{F})$ & Percent $\mathbf{( \% )}$ \\
\hline Stable & 12 & 44 \\
Unstable & 15 & 56 \\
Total & $\mathbf{2 7}$ & $\mathbf{1 0 0 \%}$ \\
\hline
\end{tabular}

Results presented on table 4.11 reveal that $56 \%$ of the respondents considered political environment in the country as unstable while $44 \%$ of the respondents consider it as stable. The majority said political environment was unstable, this response was attributed to the prolonged political season in Kenya and disputed presidential elections when the data was collected.

Table 4.12: Effects of Political Environment on PPPs

\begin{tabular}{lll}
\hline & Frequency $(\mathbf{F})$ & Percent $(\%)$ \\
\hline Yes & 18 & $69 \%$ \\
No & 8 & $21 \%$ \\
Total & $\mathbf{2 7}$ & $\mathbf{1 0 0 \%}$ \\
\hline
\end{tabular}

Findings presented on table 4:12 reveal that $69 \%$ of the respondents agree that political environment has an impact on the implementation of PPP projects in Kenya. This is because a stable political environment provides a conducive environment for investment by the private sector. In addition, presence of a stable political environment is an indication of peaceful coexistence among people especially in a society where political persuasions are based on one's tribe.

Table 4.13: Indicators of Political Environment

\begin{tabular}{|c|c|c|c|c|c|c|c|}
\hline Variables & 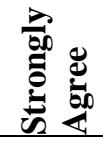 & 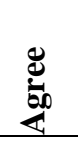 & है & 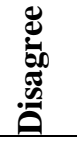 & 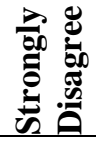 & 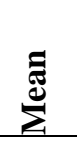 & $\begin{array}{l}\vec{U} \\
\dot{D} \\
\dot{D}\end{array}$ \\
\hline $\begin{array}{l}\text { Stakeholders are involved to } \\
\text { build consesus. }\end{array}$ & $23 \%$ & $45 \%$ & $3 \%$ & $10 \%$ & $19 \%$ & 3.42 & 1.455 \\
\hline The project has faced court cases. & $36 \%$ & $29 \%$ & $16 \%$ & $19 \%$ & $0 \%$ & 3.81 & 1.138 \\
\hline $\begin{array}{l}\text { The project has enjoyed political } \\
\text { support. }\end{array}$ & $19 \%$ & $32 \%$ & $23 \%$ & $16 \%$ & $10 \%$ & 3.35 & 1.252 \\
\hline $\begin{array}{l}\text { Leaders who implemented the } \\
\text { PPP project are popular. }\end{array}$ & $19 \%$ & $32 \%$ & $19 \%$ & $23 \%$ & $7 \%$ & 3.35 & 1.226 \\
\hline
\end{tabular}

The findings presented on table 4.13 indicated that $23 \%$ of the respondents strongly agreed that stakeholders were involved in the implementation of PPPs, $45 \%$ agreed while $19 \%$ of the respondents strongly disagreed with the statement (mean=3.42, Std=1.455). The involvement of stakeholders is critical in building consensus, promoting creativity and creating ownership of public projects. This is supported by Nederhand and Klijn (2016) who argue that stakeholder involvement promotes innovation in 
PPP projects. On the other hand, $36 \%$ of the respondents in the study strongly agreed with the statement that PPP project (s) implemented faced a court case (s) at some point in their implementation. Also $29 \%$ of the respondents agreed with the statement while $19 \%$ of the respondents disagreed (mean=3.81, $S t d=1.138$ ). Court cases usually emerge out of disagreements between or among stakeholders involved in the project. The principal-agent relationship that exists between a public and a private entity is often shrouded by conflicting interests that may necessitate the intervention of a court which often delays implementation of PPP projects. This view is shared by Odoemena and Horita (2018) who notes that risks and conflicting interests may affect implementation of PPPs especially in situations where parties involved cannot resolve them amicably. On the statement that the projects enjoyed political support, $19 \%$ of the respondents strongly agreed with the statement that the PPP project had political support during implementation, $32 \%$ agreed with the statement while $16 \%$ of the respondents disagreed ( $m e a n=3.35, S t d=1.252$ ). On the popularity of leadership implementing PPP projects, $19 \%$ of the respondents strongly agreed with the statement, $32 \%$ of the respondents agreed while $23 \%$ of the respondents disagreed (mean $=3.35$, $S t d=1.226$ ). The findings reveal that majority of respondents either agreed or strongly agreed that political environment had an impact on the implementation of PPPs in Kenya. The respondents specifically identified court cases and stakeholder involvement as the main issues that had impact on implementation of PPPs. These findings could explain low rate of completion of PPP projects despite many organizations expressing interests during Project Preparation and Appraisal stage.

\subsubsection{Correlation between political environment and implementation of PPPs in Kenya.}

The study conducted correlation analysis in order to ascertain the relationship and the associations between political environment and implementation of PPPs in Kenya. The findings are presented in Table 4.14.

Table 4.14. Correlation between political environment and implementation of PPPs in Kenya

\begin{tabular}{lll}
\hline & & Implementation of PPPs \\
\hline Political Environment & Pearson Correlation & $-.485^{* *}$ \\
& Sig. (2-tailed) & .005 \\
& $\mathrm{~N}$ & 31 \\
\hline
\end{tabular}

Correlation is significant at the 0.05 level (2-tailed)

The findings in Table 4.14 indicate a negative significant relationship that exist between political environment and implementation of PPP projects 
in Kenya ( $\mathrm{r}=-0.485, \mathrm{p}<0.05)$. This implies that political environment is inversely proportional to the implementation of PPPs in Kenya. The findings of this study echoes the findings by Wang, Liu, Xiong and Song (2019) who argue that high level governance and political control in the management of PPPs reduces negative influence in the implementation of the project. This view is further supported by Babatunde, Perera, Zhou and Udeaja (2015) who argue that politicisation of PPP processes and political bottlenecks are among the key barriers to implementation of PPPs in developing countries. Therefore, managers charged with implementation of PPPs in Kenya should strive to control political environment to ensure successful implementation of PPPs.

\section{Conclusion}

The indicators of the political environment were stakeholder involvement, court cases, political support of the project and popularity of leaders who implemented PPPs. The study revealed that majority of the respondents agreed with the statements that stakeholder involvement was conducted, PPP projects faced court cases, PPP projects enjoyed political support and leaders who supported PPP projects were popular. The high level of stakeholder involvement in PPP projects in Kenya can be attributed to the Constitutional requirement of citizen involvement in all public decision making process. The popularity of leaders who implement PPPs projects and political support of the PPP projects can be attributed to the intensive nature of the capital involved as well as political mileage that come with such projects. The study indicated that the political environment was statistically significant to the implementation of PPP projects in Kenya.

\section{Recommendations}

Based on the findings, the study recommended the following interventions on policy, practice and methodology on implementatin of PPPs.

- Stakeholder involvement play a pivotal role in ensuring successful implementation of PPPs in Kenya. Although public participation is a Constitutional requirement in the public decision making process, the Public Private Partnership unit should develop guidelines for stakeholder involvement to ensure uniformity and coherence in stakeholder engagement during implementation of PPPs in Kenya. This is likely to minimize incidences of the public contesting the projects in courts.

- Corruption poses a monumental risk to successful implementation of public private partnerships in Kenya. This is because of the intensive capital expenditure involved, thereby, making public Private Partnership Projects attractive to corrupt individuals. The researcher recommendeds that the government develops strigent measures and 
policies aimed at sealing corruption loopholes that may be exploited by stakeholders.

\section{References:}

1. Alderman, A. K., \& Salem, B. (2010). Survey research. Plastic and Reconstructive Surgery, 126(4); 1381-1389

2. Babatunde, S. O., Perera, S., Zhou, L., \& Udeaja, C. (2015). Barriers to public private partnership projects in developing countries: A case of nigeria. Engineering, Construction and Architectural Management, 22(6), 669-691. doi:10.1108/ECAM-12-2014-0159

3. Bhasin, J., \& Sadhu, J. (2010). Public private partnership. Political Economy Journal of India, 19(1), 83.

4. Bakibinga, P., Ettarh, R., Ziraba, A. K., Kyobutungi, C., Kamande, E., Ngomi, N., \&Osindo, J. (2014). The effect of enhanced publicprivate partnerships on maternal, newborn and child health services and outcomes in nairobi-kenya: The PAMANECH quasiexperimental research protocol. BMJ Open, 4(10)

5. Carpintero, S., \& Siemiatycki, M. (2016). The politics of delivering light rail transit projects through public-private partnerships in spain: A case study approach. Transport Policy, 49, 159-167. doi:10.1016/j.tranpol.2016.05.001

6. Daniel, A., Germà, B., \& Albert, G. (2019). Politics, risk, and white elephants in infrastructure PPPs. Utilities Policy, 58, 158-165. doi:10.1016/j.jup.2019.05.001

7. Emilija, S., (2013). Public Private Partnership: Coca-Cola and the University of Belgrade, International Journal of Public Sector Management, Vol. 26(2); 146-152.

8. Fombad, M. C. (2015). Governance in Public-Private Partnerships in South Africa: Some Lessons from the Gautrain. Journal of Southern African Studies, 41(6); 1199-1217

9. Gor, S.O. \& Gitau, C.M.W. (2010) Developing a sustainable funding framework to support the road transport sub-sector in KenyaWhat role for public-private partnerships? Publication can be found: http://erepository.uonbi.ac.ke:8080/xmlui/handle/123456789/ 41196

10. Jacobson, C. \& Choi, S. O., (2008) Success factors: public works and public-private partnerships, International Journal of Public Sector Management, Vol. 21 (6); 637 - 657.

11. Jensen, M.C. \& Meckling, W.H.. (1976), Theory of the Firm: Managerial Behaviour, Vol. 6(2); 264-283

12. Khaled, M. A., Nor'Aini, Y \& Ernawati M. K., (2015). External factors influencing the readiness for implementing public- 
private partnerships among public and private organizations in Yemen, Journal of Science \& Technology Policy Management, Vol. 6 (1); 56-75.

13. Kaur, N. (2012). Public-private partnership. Journal of Interdisciplinary Dentistry, Vol. 2(3)

14. Kimani, B. W., Waweru, K. M., \& Omondi, H. R. (2015). Reengineering investment in students' accommodation in public universities through public-private partnerships in kenya. Journal of Business Studies Quarterly, 7(2); 1-10.

15. Mouraviev, N., \& Kakabadse, N. K. (2016). Conceptualizing publicprivate partnerships. Society and Business Review, 11(2); 155-173.

16. Musyoka, C.A., (2012). Factors influencing the performance of public private partnerships in the Kenyan housing sector. University of Nairobi. Unpublished paper.

17. Mzikayise, S. B. (2009). A public-private partnership model for the improvement of local economic development in South African metropolitan government. PHD Thesis, Nelson Mandela Metropolitan University (NMMU).

18. Nederhand, J., \& Klijn, E. H. (2016). Stakeholder involvement in Public-Private partnerships: Its influence on the innovative character of projects and on project performance. Administration \& Society, 9539971668488. doi:10.1177/0095399716684887

19. Ngowi (2011) Public -Private Partnership in Service Delivery: Application, Reasons, Procedures, Results and Challenges in Tanzania Local Government Authorities www.unpan.un.org last accessed on $4^{\text {th }}$ August 2011.

20. Odoemena, A. T. \& Horita, M. (2018). A strategic analysis of contract termination in public- private partnerships: Implications from cases in sub-Saharan Africa. Construction Management and Economics, 36(2), 96-108. doi:10.1080/01446193.2017.1361039

21. Opara, M., Elloumi, F., Okafar, O. \& Warsame, H. (2017) Effects of the institutional environment on public private partnership (P3): Evidence from Canada, Accounting Forum, Vol. 41 (2); 77-95

22. Parker, D. W., Dressel, U., Chevers, D. \& Zeppetella, L. (2018). Agency theory perspective on public-private-partnerships: International development project. International Journal of Productivity and Performance Management, 67(2); 239-247.

23. Rangi, D.K. (2013). The influence of Public-Private Partnerships on the relationship between market access and performance of small and medium horticultural enterprises in Kenya. Unpublished $\mathrm{PhD}$ Thesis. Kenyatta University. 
24. Rania, G. (2008). Overview on the development of Egyptian PPP program: PPPs a Transformational Development Tool to improve access to Reliable \& Affordable Infrastructure Services, Ministry of Finance, PPP central Unit.

25. Sachs, T., Tiong, R., \& Wang, S. Q. (2007). Analysis of political risks and opportunities in public private partnerships (PPP) in china and selected Asian countries. Chinese Management Studies, Vol. 1(2); 126-148.

26. Saunders, M., Lewis, P. \& Thornhill, A. (2009). Research Methods for Business Students, $5^{\text {th }} \quad$ (Ed.) England. Pearson Education Limited.

27. Straub, S (2008). Infrastructure and growth in developing countries: recent advances and research challenges, The world Bank Developments Research Department. World Bank. New York.

28. Suchman, L., Hart, B. A., \& Montagu, D. (2018). Public-private partnerships in practice: Collaborating to improve health finance policy in ghana and kenya. Health Policy and Planning, 33(7), 877-877. doi:10.1093/heapol/czy064

29. The Constitution of Kenya, 2010

30. The World Bank (2017). Private participation in infrastructure (PPI): Annual Report. Saha, D., Hong S. H., Shao Alex, Modi. A., and Zemlytska, I. Retrieved from: http://ppi.worldbank.org/ /media/GIAWB/PPI/Documents/GlobalNotes/PPI_2017_AnnualReport.pdf

31. Twitchen, C., \& Adams, D. (2012). Using web technology to increase levels of public participation in planning. The Town Planning Review, Vol. 83(6); 7-13.

32. Walaa W. E., (2018). Corporate governance risk and the agency problem: Corporate Governance. The International Journal of Business in Society, Vol. 18 Issue: 2, pp.254-269.

33. Wang, H., Liu, Y., Xiong, W., \& Song, J. (2019). The moderating role of governance environment on the relationship between risk allocation and private investment in PPP markets: Evidence from developing countries. International Journal of Project Management, 37(1), 117-130. doi:10.1016/j.ijproman.2018.10.008. 